\title{
Blossom-end Rot Incidence of Tomato as Affected by Irrigation Quantity, Calcium Source, and Reduced Potassium
}

\author{
M.D. Taylor, S.J. Locascio, and M.R. Alligood \\ Horticultural Science Department, University of Florida, Gainesville, FL \\ 32611 \\ Additional index words. calcium nitrate, gypsum, calcium chloride, calcium thiosulfate
}

Abstract. 'Equinox' tomatoes (Lycopersicon esculentum Mill.) were grown during the springs of 2001 and 2002 with black polyethylene-mulch and drip irrigation on an Arredondo fine sand in Gainesville, Fla., to study the influence of water quantity, Ca source, and reduced $\mathrm{K}$ on incidence of blossom-end rot (BER), marketable fruit yield, and fruit and leaf $\mathrm{Ca}$ concentration. Tensiometers were used to schedule irrigation in main plots when the soil matric potential reached 10 or $25 \mathrm{kPa}$. Subplot nutritional treatments were no added Ca, $\mathrm{Ca}\left(\mathrm{NO}_{3}\right)_{2}$, Ca thiosulfate, $\mathrm{CaCl}_{2}, \mathrm{CaSO}_{4}$, and $\mathrm{K}$ rate reduced by $50 \%$. Interactions between year and treatment were significant. During 2001, total marketable yields were higher with $\mathrm{Ca}\left(\mathrm{NO}_{3}\right)_{2}$ or $\mathrm{CaCl}_{2}$ compared to plants that received $\mathrm{Ca}$ thiosulfate and were higher from plants irrigated at $10 \mathrm{kPa}$ than irrigated at $25 \mathrm{kPa}$. Number and weight of BER fruit were lower with $\mathrm{Ca}\left(\mathrm{NO}_{3}\right)_{2}$ and reduced $\mathrm{K}$ than with no added $\mathrm{Ca}$ and $\mathrm{CaSO}_{4}$. Leaf and fruit $\mathrm{Ca}$ concentrations were generally higher with $\mathrm{Ca}\left(\mathrm{NO}_{3}\right)_{2}$ compared to all other nutritional treatments. Leaf and fruit $\mathrm{Ca}$ concentrations were generally higher from plants irrigated at 10 $\mathrm{kPa}$ than at $25 \mathrm{kPa}$. The reduction of $\mathrm{NH}_{4}{ }^{+} \mathrm{N}$, by the supply of $\mathrm{N}$ as $\mathrm{NO}_{3}^{-}$, and the addition of supplemental Ca reduced the incidence of BER, and increased the leaf and fruit Ca concentrations. During 2002, marketable yields were higher with $\mathrm{CaSO}_{4}$ than with $\mathrm{CaCl}_{2}$ and reduced $\mathrm{K}$. Weight and number of BER fruit were lower with irrigation at $10 \mathrm{kPa}$ than at $25 \mathrm{kPa}$. Leaf and fruit Ca concentrations were higher or similar from plants that received $\mathrm{Ca}\left(\mathrm{NO}_{3}\right)_{2}$ than with all other nutritional treatments. During the 2002 season, rainfall was less and temperatures and daily evapotranspiration (ET) were higher than in the 2001 season. In the 2002 season, $3.28 \times 10^{6} \mathrm{~L} \cdot \mathrm{ha}^{-1}$ of irrigation was applied as compared to 1.58 $\times 10^{6} \mathrm{~L} \cdot \mathrm{ha}^{-1}$ in 2001. With an average Ca concentration of $76 \mathrm{mg} \cdot \mathrm{L}^{-1}$ in the irrigation water, much more Ca was applied during the higher ET 2002 season. With the higher transpiration and temperature, water uptake and hence, Ca uptake were increased. During both seasons, the lowest $\mathrm{Ca}$ concentration was observed at the blossom end of the fruit and the highest $\mathrm{Ca}$ at the stem end of the fruit. Fruit Ca concentrations were lower and BER was 5 times higher in the lower ET, higher rainfall (lower irrigation) 2001 season compared to the higher ET, lower rainfall (higher irrigation) 2002 season. These data support that BER was a symptom of $\mathrm{Ca}$ deficiency and this deficiency was aggravated by high rainfall, low ET, and the resulting reduced irrigation applied and reduced Ca uptake.

Blossom-end rot (BER) of tomato is a problem that was first described as black-rot (Galloway, 1888). BER is a common physiological disorder that occurs on tomato, pepper (Capsicum annuum L), eggplant (Solanum melongena L.), and watermelon [Citrullus lanatus (Thunb.) Matsun \& Nakai] that is common in all the tomato-producing areas of the world and has been shown to create losses up to $50 \%$ (Geraldson, 1955). BER is caused by many factors but the underlying cause of this disorder is an inadequate amount of $\mathrm{Ca}$ in the blossom-end of the fruit (Ho et al., 1995; Kitano et al., 1999; Saure, 2001). The first evidence of $\mathrm{Ca}$ involvement in BER was discovered by Raleigh and Chucka (1944), who showed that whenever the Ca content of the fruit was below $0.20 \%$, BER generally occurred. Previous studies have shown

Received for publication 29 Jan. 2003. Accepted for publication 3 July 2003. This research was supported by the Florida Agricultural Experiment Station and approved for publication as journal series R-09289. that BER is not caused by one single factor but by a combination of one or more factors intensifying the effect, including: high $\mathrm{Mg}$, $\mathrm{Na}, \mathrm{NH}_{4}$, and/or $\mathrm{K}$ concentration (Geraldson, 1955); accelerated growth rate (Marcelis and Ho, 1999; Saure 2001); low water availability (Franco et al., 1999); low soluble soil Ca (Kirby and Pilbeam, 1984); and high (Kreij, 1996) and low transpiration (Paiva et al., 1998a). Inadequate amounts of $\mathrm{Ca}$ for plant growth are rare in most soils; thus, a Ca deficiency is usually the result of poor distribution of $\mathrm{Ca}$ in relation to demand, antagonistic effects of other elements, and/or low plant transpiration (Keiser and Mullen, 1993).

The Ca concentration in the soil is usually $\approx 10$ times that of $\mathrm{K}$, but the uptake is usually lower for Ca (Kirby and Pilbeam, 1984). $\mathrm{Ca}^{2+}$ is a divalent ion and as ions increase in valence, uptake decreases (Marschner, 1997). Geraldson (1956) suggested excessive soluble K, Na, or $\mathrm{NH}_{4}$ (monovalent ions) caused decreased $\mathrm{Ca}$ uptake and increased incidence of BER in tomato. Locascio et al. (1991) showed that increasing $\mathrm{K}$ fertilization significantly reduced
Ca content of potato leaf and medulla tissue. When fertilizing with $\mathrm{N}$, the use of $\mathrm{NO}_{3}^{-}{ }_{-} \mathrm{N}$ stimulates Ca uptake, as compared to $\mathrm{NH}_{4}^{+}$$\mathrm{N}$, which depresses $\mathrm{Ca}$ uptake (English et al., 1983).

Calcium movement through the plant and accumulation in fruit is correlated with transpirational movement of water (Keiser and Mullen, 1993). Rapidly growing transpiring leaves or stems that have a higher surface area than fruit transpire at a higher rate than fruit (Kirby and Pilbeam, 1984) and act as competing sinks with fruit for directional $\mathrm{Ca}$ flow and use (McLaughlin and Wimmer, 1999). Increasing plant tissue $\mathrm{Ca}$ concentration is more likely a result of altered flux of $\mathrm{Ca}$ in xylem sap (e.g., higher transpiration rate) rather than from increased Ca supply to the roots (Kleinhenz et al., 1999). Different environmental factors, such as temperature, humidity, and soil water content influence transpiration rates of the plant. Tadesse et al. (2001) showed that high relative humidity induced the incidence of BER and that low relative humidity reduced incidence of BER in sweet pepper. In this experiment, the incidence of BER and high relative humidity was significantly correlated with low $\mathrm{Ca}$ concentrations.

Even though $\mathrm{Ca}$ depends on water to get into and throughout the plant, not many studies have been performed to evaluate different irrigation quantities on the incidence of BER. In a study by Reid et al. (1996), incidence of $\mathrm{BER}$ was greater and tomato fruit $\mathrm{Ca}$ content was lower from plants that were not irrigated compared to irrigated plants. In an experiment by Franco et al. (1999), water stress (25 d after planting irrigation reduced by one-half until the end of the season) significantly increased the incidence of BER in drip-irrigated tomatoes.

Maximum relative growth rate of tomato fruit occurs at 12 to $15 \mathrm{~d}$ after anthesis (Saure, 2001). During this period of rapid cell expansion, Ca is essential to prevent BER. Deficiency of $\mathrm{Ca}$ is most disastrous during this period of rapid cell expansion in the fruit 1 to 3 weeks after anthesis (Willumsen et al., 1996). Many other researchers agree that the incidence of BER mostly occurs at about the second week after anthesis (Saure, 2001).

The objective of this study was to evaluate the influence of water quantity as controlled by tensiometers, Ca source, and reduced $\mathrm{K}$ on fruit yield, leaf and fruit $\mathrm{Ca}$ and $\mathrm{K}$ concentrations, and incidence of BER.

\section{Materials and Methods}

'Equinox' tomatoes were grown with black polyethylene-mulch and drip irrigation on an Arredondo (loamy, siliceous, hyperthemic Grossarenic Paleudults) fine sand at the Univ. of Florida Horticultural Unit in Gainesville during Spring 2001 to evaluate water quantity and $\mathrm{Ca}$ treatment on growth of tomato. The six nutritional treatments were: no added $\mathrm{Ca}$, $\mathrm{Ca}\left(\mathrm{NO}_{3}\right)_{2}$ as sole drip $\mathrm{N}$ source (total Ca at 165 $\left.\mathrm{kg} \cdot \mathrm{ha}^{-1}\right)$, Ca thiosulfate solution $\left(\mathrm{CaS}_{2} \mathrm{O}_{3} ; 6.4 \%\right.$ Ca) at $37.4 \mathrm{~L} \cdot \mathrm{ha}^{-1}$ split into four applications applied through the drip system once a week from week 4 through 7 after transplanting (total 
$\mathrm{Ca}$ at $\left.12 \mathrm{~kg} \cdot \mathrm{ha}^{-1}\right), \mathrm{CaCl}_{2}$ drip-applied once a week from week 1 through 10 after transplanting (total $\mathrm{Ca}$ at $82.5 \mathrm{~kg} \cdot \mathrm{ha}^{-1}$ ), $\mathrm{CaSO}_{4}$ applied preplant (total $\mathrm{Ca}$ at $592 \mathrm{~kg} \cdot \mathrm{ha}^{-1}$ ), and $\mathrm{K}$ rate reduced by $50 \%$ from 168 to $84 \mathrm{~kg} \cdot \mathrm{ha}^{-1}$ (with no added $\mathrm{Ca}$ ). Water treatments were controlled with tensiometers used to automatically schedule irrigation by opening solenoid valves on demand when soil matric potential $(\mathrm{kPa})$ reached threshold values of 10 (wetter) or 25 $\mathrm{kPa}$ (dryer) (10 or $25 \mathrm{cb}$ ). Two tensiometers were installed per water treatment, one at a soil depth of $15 \mathrm{~cm}$ and the other at $30 \mathrm{~cm}$, midway between the plants. The system was designed so that tensiometers monitored soil matric potential 3 times daily. Tensiometers were wired in parallel so that either one of the two could initiate an irrigation of 0.75 pan measured the previous week (Smajstrla and Locascio, 1996). Treatments were arranged in a randomized complete-block design with five replications in plots $1.8 \mathrm{~m}$ wide $\times 10.7 \mathrm{~m}$ long. $1.8 \mathrm{~m}$ apart, were formed. Beds were fumigated with $362 \mathrm{~kg} \cdot \mathrm{ha}^{-1}$ methyl bromide, 131 $\mathrm{kg} \cdot \mathrm{ha}^{-1}$ chloropicrin mix, and covered with 0.0038 -cm-thick black polyethylene mulch on 29 Feb. 2001. Fertilizer was applied at 225-25-168-34-45 kg.ha- ${ }^{-1} \mathrm{~N}-\mathrm{P}-\mathrm{K}-\mathrm{S}-$ micronutrient. A preplant application of $40 \% \mathrm{~N}$ and $\mathrm{K}$ and all other nutrients were broadcast and incorporated into beds. The remaining $60 \%$ of the $\mathrm{N}$ and $\mathrm{K}$ was applied through the drip system once a week for 10 weeks, starting 8 $\mathrm{d}$ after transplanting (DAT). Fertilizer sources
The soil was disked and 0.9-m-wide beds,

for preplant-applied nutrients were $\mathrm{NH}_{4} \mathrm{NO}_{3}$, triple-super phosphate, $\mathrm{KCl}, \mathrm{MgSO}_{4}$, and FTE503 (Frit Industries, Ozark, Ala.). Double-wall drip tubing (Chapin Twinwall, Watertown, N.Y.), with emitters $30.5 \mathrm{~cm}$ apart with a delivery rate of $62 \mathrm{~mL} \cdot \mathrm{m}^{-1} \cdot \mathrm{min}^{-1}$, was placed 7.5 to $10 \mathrm{~cm}$ from the bed center.

Tomatoes were transplanted $0.5 \mathrm{~m}$ apart on 13 Mar. 2001 and were overhead-irrigated when needed for a week until established. Soil samples were taken 51 DAT and analyzed for $\mathrm{Ca}$ and $\mathrm{K}$ with Mehlich-I procedures (Page et al., 1982). Recently matured whole leaves (eight per plot) and green fruit $\approx 2 \mathrm{~cm}$ in size (three per plot) were harvested 57 DAT and ripe fruit (four per plot) were harvested 90 DAT. All fruit were equally divided into stem-end, middle, and blossom end.

Leaf and fruit tissue were dried in a forcedair drier at $70{ }^{\circ} \mathrm{C}$. The $\mathrm{K}$ and $\mathrm{Ca}$ concentrations were determined by dry ash procedure using 500-mg samples ashed at $500{ }^{\circ} \mathrm{C}$ for $10 \mathrm{~h}$, diluted in $50 \mathrm{~mL}$ of $1 \mathrm{M} \mathrm{HCl}$, and analyzed by inductively coupled plasm spectrophotometer (ICPS) (Kalra, 1998). Fruit were harvested 84,92 , and 99 DAT at the mature green to red stage. BER fruit were separated and remaining fruit graded into extra large ( $>73 \mathrm{~mm}$ in diameter), large (64-73 mm), and medium (58-63 $\mathrm{mm}$ ) sizes of marketable fruit and weighed (USDA, 1976).

The above 2001 study was duplicated in 2002 where all treatment combinations and cultural practices were similar to Spring 2001 except for some factors described below.

Table 1. Season length, average daily evapotranspiration (ET), average daily rainfall, and average minimum and maximum temperatures, Spring 2001 and 2002.

\begin{tabular}{lccccc}
\hline Year & $\begin{array}{c}\text { Season } \\
\text { length }(\mathrm{d})\end{array}$ & $\begin{array}{c}\text { Avg daily } \\
\text { ET }(\mathrm{cm})\end{array}$ & $\begin{array}{c}\text { Avg daily } \\
\text { rainfall }(\mathrm{cm})\end{array}$ & $\begin{array}{c}\text { Avg min } \\
\text { temp }\left({ }^{\circ} \mathrm{C}\right)\end{array}$ & $\begin{array}{c}\text { Avg max } \\
\text { temp }\left({ }^{\circ} \mathrm{C}\right)\end{array}$ \\
\hline 2001 & 99 & 0.43 & 0.35 & 13.1 & 27.7 \\
2002 & 90 & 0.46 & 0.10 & 15.3 & 29.3 \\
Significance & & $*$ & $* *$ & $* *$ & $* *$ \\
\hline
\end{tabular}

${ }_{\text {Ns, }, * * *}^{*}$ Nonsignificant or significant at $P=0.10$ and 0.01 , respectively.
Planting date was 19 Mar. 2002 and fruit were harvested 77 and 90 DAT at the mature green to red stage. Data were statistically analyzed by analysis of variance using SAS version 8.02 and Duncan's procedure (SAS Institute, 2002).

\section{Results and Discussion}

The 2001 and 2002 seasons were 99 and 90 d in length from transplant to the final harvest, respectively (Table 1). Average minimum and maximum temperatures were higher in 2002 than 2001. Daily evapotranspiration (ET) values of $0.46 \mathrm{~cm}$ in 2002 were significantly higher than $0.43 \mathrm{~cm}$ in 2001, with rainfall at $0.35 \mathrm{~cm}$ per day in 2001 and significantly lower at $0.10 \mathrm{~cm}$ per day in 2002 . With the lower rainfall and higher transpiration rate in 2002 , there was much more dependence on the drip irrigation system to supply water during 2002 compared to 2001 (Table 2) when drip irrigation averaged $15.8 \mathrm{~cm}$ in 2001 and $32.8 \mathrm{~cm}$ in 2002 . Interactions between year, water treatment, and nutritional treatment were significant; thus, most data are presented by year.

During 2001, total marketable yields were significantly higher from plants that received $\mathrm{Ca}\left(\mathrm{NO}_{3}\right)_{2}$ or $\mathrm{CaCl}_{2}$, compared with plants that received $\mathrm{Ca}$ thiosulfate (Table 3 ). With an increase in irrigation from 25 to $10 \mathrm{kPa}$, total marketable fruit yield increased from 35.0 to $63.1 \mathrm{t} \cdot \mathrm{ha}^{-1}$. This was expected because $10 \mathrm{kPa}$ is recommended for this soil type for tomatoes in Florida and $25 \mathrm{kPa}$ is considered stressful. In a 4-year study by Smajstrla and Locascio (1996), in one of the 4 years and in the 4-year average there was a linear increase in marketable yield with irrigation at 20,15 , and $10 \mathrm{kPa}$. During 2002, irrigation quantities were 34.4 $\mathrm{cm}$ with $10 \mathrm{kPa}$ and $31.21 \mathrm{~cm}$ with $25 \mathrm{kPa}$ and total marketable yield was unaffected by water treatment. In past work, maximum yields were produced with water quantities between 0.5

Table 2. Quantity of water applied through irrigation system, rainfall, and evapotranspiration (ET) 1 through 13 weeks after transplanting, Spring 2001 and 2002.

\begin{tabular}{|c|c|c|c|c|c|c|c|c|}
\hline \multirow[b]{5}{*}{ Week } & \multicolumn{8}{|c|}{ Water quantity $(\mathrm{cm})$} \\
\hline & \multicolumn{4}{|c|}{2001} & \multicolumn{4}{|c|}{2002} \\
\hline & \multirow{2}{*}{\multicolumn{2}{|c|}{$\begin{array}{c}\text { Irrigation quantity } \\
\text { Water treatment }\end{array}$}} & \multirow[b]{3}{*}{ Rainfall } & \multirow[b]{3}{*}{ ET } & \multirow{2}{*}{\multicolumn{2}{|c|}{$\begin{array}{c}\text { Irrigation quantity } \\
\text { Water treatment }\end{array}$}} & \multirow[b]{3}{*}{ Rainfall } & \multirow[b]{3}{*}{ ET } \\
\hline & & & & & & & & \\
\hline & $10 \mathrm{kPa}$ & $25 \mathrm{kPa}$ & & & $10 \mathrm{kPa}$ & $25 \mathrm{kPa}$ & & \\
\hline 1 & --- & --- & 10.00 & 1.97 & --- & --- & 0.05 & 2.59 \\
\hline 2 & 0.1 & 0.1 & 2.05 & 2.21 & 0.3 & 0.2 & 0.18 & 2.86 \\
\hline 3 & 0.1 & 0.1 & 2.29 & 2.40 & 0.2 & 0.2 & 0.05 & 2.61 \\
\hline 4 & 0.2 & 0.2 & 0.00 & 2.63 & 0.2 & 0.2 & 0.81 & 2.56 \\
\hline 5 & 0.4 & 0.4 & 0.71 & 3.06 & 1.0 & 0.7 & 0.03 & 3.42 \\
\hline 6 & 1.6 & 0.4 & 0.25 & 3.03 & 3.5 & 1.2 & 0.00 & 3.42 \\
\hline 7 & 1.5 & 0.6 & 1.52 & 2.87 & 4.2 & 2.9 & 0.00 & 3.84 \\
\hline 8 & 2.1 & 1.3 & 1.14 & 3.10 & 6.6 & 4.9 & 0.00 & 3.73 \\
\hline 1-8 Total & 6.0 & 3.2 & 17.96 & 21.27 & 15.9 & 10.3 & 1.12 & 25.03 \\
\hline Year mean & & & & & & & & \\
\hline 9 & 2.3 & 1.8 & 0.03 & 3.22 & 1.3 & 3.5 & 2.21 & 3.16 \\
\hline 10 & 3.2 & 3.8 & 0.00 & 3.65 & 5.5 & 5.3 & 0.00 & 3.50 \\
\hline 11 & 2.9 & 2.0 & 4.14 & 3.74 & 6.0 & 5.4 & 1.96 & 3.75 \\
\hline 12 & 3.0 & 0.8 & 0.89 & 3.51 & 2.4 & 1.7 & 2.40 & 2.87 \\
\hline 13 & 2.1 & 0.6 & 7.74 & 3.16 & 3.4 & 5.0 & 0.28 & 3.68 \\
\hline 9-13 Total & 13.5 & 8.9 & 12.80 & 17.28 & 18.5 & 21.0 & 6.85 & 16.96 \\
\hline Total & 19.5 & 12.1 & 30.78 & 38.55 & 34.4 & 31.2 & 7.98 & 41.99 \\
\hline Year mean & & & & & & & & \\
\hline
\end{tabular}


Table 3. Main effects of nutritional treatment and water treatment on total marketable yield and total weight and number of blossom-end-rot (BER) fruit, Spring 2001 and 2002.

\begin{tabular}{|c|c|c|}
\hline & \multicolumn{2}{|c|}{ Marketable yield $\left(\mathrm{t} \cdot \mathrm{ha}^{-1}\right)$} \\
\hline & \multicolumn{2}{|c|}{ Year } \\
\hline & 2001 & 2002 \\
\hline \multicolumn{3}{|l|}{ Nutritional treatment } \\
\hline No added $\mathrm{Ca}$ & $44.5 \mathrm{ab}^{\mathrm{z}}$ & $78.9 \mathrm{ab}$ \\
\hline $\mathrm{Ca}\left(\mathrm{NO}_{3}\right)_{2}$ & $50.4 \mathrm{a}$ & $79.0 \mathrm{ab}$ \\
\hline Ca Thiosulfate & $36.9 \mathrm{~b}$ & $78.6 \mathrm{ab}$ \\
\hline $\mathrm{CaCl}_{2}$ & $50.3 \mathrm{a}$ & $75.2 \mathrm{~b}$ \\
\hline $\mathrm{CaSO}_{4}$ & $40.9 \mathrm{ab}$ & $84.2 \mathrm{a}$ \\
\hline $1 / 2 \mathrm{KCl}$ & $44.5 \mathrm{ab}$ & $71.1 \mathrm{~b}$ \\
\hline \multicolumn{3}{|l|}{ Water treatment } \\
\hline $10 \mathrm{kPa}$ & $57.4 \mathrm{a}$ & $76.8 \mathrm{a}$ \\
\hline $25 \mathrm{kPa}$ & $31.8 \mathrm{~b}$ & $78.9 \mathrm{a}$ \\
\hline \multirow{2}{*}{$\begin{array}{l}\text { Nutritional treatment } \\
\text { No added } \mathrm{Ca}\end{array}$} & \multicolumn{2}{|c|}{ BER wt $\left(\mathrm{t} \cdot \mathrm{ha}^{-1}\right)$} \\
\hline & $9.7 \mathrm{a}$ & $1.5 \mathrm{a}$ \\
\hline $\mathrm{Ca}\left(\mathrm{NO}_{3}\right)_{2}$ & $6.5 \mathrm{~b}$ & $1.0 \mathrm{a}$ \\
\hline Ca Thiosulfate & $9.8 \mathrm{a}$ & $1.1 \mathrm{a}$ \\
\hline $\mathrm{CaCl}_{2}$ & $8.1 \mathrm{ab}$ & $1.7 \mathrm{a}$ \\
\hline $\mathrm{CaSO}_{4}$ & $9.7 \mathrm{a}$ & $1.1 \mathrm{a}$ \\
\hline $1 / 2 \mathrm{KCl}$ & $6.7 \mathrm{~b}$ & $1.3 \mathrm{a}$ \\
\hline \multicolumn{3}{|l|}{ Water treatment } \\
\hline $10 \mathrm{kPa}$ & $5.6 \mathrm{~b}$ & $1.0 \mathrm{~b}$ \\
\hline $25 \mathrm{kPa}$ & $11.2 \mathrm{a}$ & $1.6 \mathrm{a}$ \\
\hline \multirow{2}{*}{$\begin{array}{l}\text { Nutritional treatment } \\
\text { No added } \mathrm{Ca}\end{array}$} & \multicolumn{2}{|c|}{ BER no. (1000s/ha) } \\
\hline & $86.6 \mathrm{a}^{\mathrm{z}}$ & $10.1 \mathrm{a}$ \\
\hline $\mathrm{Ca}\left(\mathrm{NO}_{3}\right)_{2}$ & $50.5 \mathrm{c}$ & $7.8 \mathrm{a}$ \\
\hline Ca Thiosulfate & $78.0 \mathrm{ab}$ & $8.3 \mathrm{a}$ \\
\hline $\mathrm{CaCl}_{2}$ & $64.6 \mathrm{abc}$ & $12.3 \mathrm{a}$ \\
\hline $\mathrm{CaSO}_{4}$ & $89.5 \mathrm{a}$ & $7.9 \mathrm{a}$ \\
\hline $1 / 2 \mathrm{KCl}$ & $58.1 \mathrm{bc}$ & $9.0 \mathrm{a}$ \\
\hline \multicolumn{3}{|l|}{ Water treatment } \\
\hline $10 \mathrm{kPa}$ & $43.6 \mathrm{~b}$ & $6.6 \mathrm{~b}$ \\
\hline $25 \mathrm{kPa}$ & $98.9 \mathrm{a}$ & $11.8 \mathrm{a}$ \\
\hline
\end{tabular}

${ }^{2}$ Mean separation (in column) by Duncan's multiple range test.

and 1.0 pan (Locascio and Smajstrla, 1996). In 2002 , fruit yields were higher from plants that received $\mathrm{CaSO}_{4}$ than from plants that received $\mathrm{CaCl}_{2}$ or reduced $\mathrm{K}$. This suggests the $\mathrm{K}$ rate was below the plants' requirements for optimal fruit production, and the reduction in Kapplication in the higher irrigation 2002 season than in 2001 caused a reduction in marketable yield (Locascio et al., 1997). During the latter half of the drier 2002 season, the plants demand for water was high compared to earlier in the season. Marketable yield was considerably higher in 2002 compared to 2001. These differences were attributed to higher minimum and maximum temperatures and less BER fruit during the 2002 season.

During 2001, numbers of BER fruit were lower from plants that received $\mathrm{Ca}\left(\mathrm{NO}_{3}\right)_{2}$ than from plants that received all other nutritional treatments except $\mathrm{CaCl}_{2}$ and reduced $\mathrm{K}$, and was lower from plants that received reduced $\mathrm{K}$ compared to plants that received no added $\mathrm{Ca}$ or $\mathrm{CaSO}_{4}$ (Table 3). Weights of BER fruit were lower with $\mathrm{Ca}\left(\mathrm{NO}_{3}\right)_{2}$ or reduced $\mathrm{K}$ compared to plants that received no added $\mathrm{Ca}, \mathrm{Ca}$ thiosulfate, or $\mathrm{CaSO}_{4}$. These results suggest that reducing $\mathrm{NH}_{4}^{+}-\mathrm{N}$, supplying $\mathrm{N}$ as $\mathrm{NO}_{3}^{-}$, and adding supplemental Ca reduced the incidence of BER In a study by DeKock et al. (1982) BER percentages were significantly higher with $\mathrm{NH}_{4}^{+}-\mathrm{N}$ than with $\mathrm{NO}_{3}^{-}{ }^{-} \mathrm{N}$. There is a competition between cations for root absorption sites, and monovalent cations $\left(\mathrm{K}^{+}\right.$ and $\mathrm{NH}_{4}^{+}$) are absorbed more readily than divalent cations $\left(\mathrm{Ca}^{2+}\right)$ (Marschner, 1997). Reducing the amount of $\mathrm{K}^{+}$and $\mathrm{NH}_{4}^{+}$in soil reduced the incidence of BER in 2001. Geraldson (1956) showed excessive $\mathrm{K}^{+}$or $\mathrm{NH}_{4}^{+}$ caused an increase in the prevalence and severity of BER.

During 2001, the number of BER fruit decreased from 98,900 to $43,600 /$ ha and weight of BER fruit decreased from 11.2 to $5.6 \mathrm{t} \cdot \mathrm{ha}^{-1}$, for plants irrigated at 25 and $10 \mathrm{kPa}$, respectively (Table 3). During Spring 2002 there was no effect of nutritional treatment on number or weight of BER fruit. With an increase in irrigation from 25 to $10 \mathrm{kPa}$, the number and weight of BER fruit increased significantly from 6,600 to 11,800 /ha and 1.0 to $1.6 \mathrm{t} \cdot \mathrm{ha}^{-1}$, respectively. During both years, the number and weight of BER fruit were lower from plants irrigated at $10 \mathrm{kPa}$ compared to plants irrigated at $25 \mathrm{kPa}$. These results are consistent with a report by Franco et al. (1999), where the occurrence of BER was lower with a higher quantity of irrigation. Since plant $\mathrm{Ca}$ moves with the transpiration stream through the xylem to growing fruit, soil water content is very important for Ca uptake (Hanger, 1979; Kitano et al., 1999).

During 2002, the amount of water applied with the 10 and $25 \mathrm{kPa}$ treatments were 34.4 and $31.2 \mathrm{~cm}$, respectively. The differences in the treatment totals were much less compared to the 2001 season. These data suggest that the effect of water treatment during the 2002 season on BER would be minimal. The maximum relative growth rate of tomato fruit occurs at 12 to $15 \mathrm{~d}$ after anthesis (Saure, 2001), the period where $\mathrm{Ca}$ is essential to prevent BER. Eight weeks after transplanting was the time that $2-\mathrm{cm}$ fruit were sampled. Comparing water application quantities at 8 weeks after transplanting, the 10 and $25 \mathrm{kPa}$ treatments received 15.9 and $10.3 \mathrm{~cm}$ of water, respectively. These differences accounted for the increased incidence of BER from plants irrigated at 25 $\mathrm{kPa}$ compared to plants irrigated at $10 \mathrm{kPa}$, during the 2002 season.

There were considerably more BER-affected fruit during the 2001 season compared to the 2002 season. During the second season there were higher minimum and maximum temperatures, which increase plant transpiration and therefore increase water and $\mathrm{Ca}$ uptake from the soil. Average daily rainfall decreased from 0.35 to $0.10 \mathrm{~cm}$ and total rainfall decreased from 34.9 to $6.1 \mathrm{~cm}$ during the 2001 and 2002 seasons, respectively. With minimal rainfall during the 2002 season, more irrigation water was applied. During the 2001 season, $19.5 \mathrm{~cm}$ of water was applied with the $10 \mathrm{kPa}$ treatment and $12.1 \mathrm{~cm}$ of water was applied with the $25 \mathrm{kPa}$ treatment. The average $\mathrm{Ca}$ concentration in irrigation water was $75.6 \mathrm{ppm}$, so the $10 \mathrm{kPa}$ and $25 \mathrm{kPa}$ treatment received an additional 147 and 90 $\mathrm{kg} \cdot \mathrm{ha}^{-1}$ of Ca, respectively. During the 2002 season, $34.4 \mathrm{~cm}$ of water was applied with the $10 \mathrm{kPa}$ treatment and $31.2 \mathrm{~cm}$ of water was applied with the $25 \mathrm{kPa}$ treatment. The average $\mathrm{Ca}$ concentration in the irrigation water was $76.4 \mathrm{ppm}$, so with the 10 and 25 $\mathrm{kPa}$ treatment received, an additional 262 and $238 \mathrm{~kg} \cdot \mathrm{ha}^{-1}$ of $\mathrm{Ca}$ was applied, respectively. This increase in irrigation water from the 2001 to the 2002 season additionally provided an average of 115 and $148 \mathrm{~kg} \cdot \mathrm{ha}^{-1}$ of $\mathrm{Ca}$ with the 10 and $25 \mathrm{kPa}$ treatments in the 2002 season, respectively. Although Ca nutritional treatments had no effect on the incidence of BER in 2002, probably the higher amount of added Ca provided by irrigation at $10 \mathrm{kPa}$ than $25 \mathrm{kPa}$ reduced the incidence of BER with irrigation at $10 \mathrm{kPa}$.

During 2001, 57 DAT leaf Ca concentrations were higher with $\mathrm{Ca}\left(\mathrm{NO}_{3}\right)_{2}$ compared to plants that received other nutritional treatment (Table 4). In Spring 2002, 57 DAT leaf Ca concentrations were higher with $\mathrm{Ca}\left(\mathrm{NO}_{3}\right)_{2}$ compared to plants that received no added $\mathrm{Ca}$ and $\mathrm{Ca}$ thiosulfate. Leaf $\mathrm{Ca}$ concentrations were unaffected by water treatment during 2001 and 2002 but were nearly twice as high in 2002 when transpiration rate was higher than in 2001. During both years, leaf K concentrations were lower from plants that received reduced $\mathrm{K}$ than with all other nutritional treatments, and $\mathrm{K}$ concentrations were unaffected by water treatment.

The Ca concentrations of 2 -cm fruit sampled 57 DAT during 2001 from plants that received $\mathrm{Ca}\left(\mathrm{NO}_{3}\right)_{2}$ were higher than with no added $\mathrm{Ca}$, Ca thiosulfate, and $\mathrm{CaSO}_{4}$ (Table 5). The Cacon- 
Table 4. Main effects of nutritional treatment and water treatment on leaf dry weight Ca and K concentrations sampled $57 \mathrm{~d}$ after transplanting (DAT), Spring 2001 and 2002.

\begin{tabular}{|c|c|c|c|c|}
\hline & \multicolumn{4}{|c|}{ Leaf concn $\left(\mathrm{g} \cdot \mathrm{kg}^{-1}\right)$} \\
\hline & \multicolumn{4}{|c|}{ Year } \\
\hline & \multicolumn{2}{|c|}{2001} & \multicolumn{2}{|c|}{2002} \\
\hline & $\mathrm{Ca}$ & $\mathrm{K}$ & $\mathrm{Ca}$ & $\mathrm{K}$ \\
\hline \multicolumn{5}{|c|}{ Nutritional treatment } \\
\hline No added $\mathrm{Ca}$ & $12.8 b^{z}$ & $24.6 \mathrm{a}$ & $20.4 \mathrm{bc}$ & $27.8 \mathrm{ab}$ \\
\hline $\mathrm{Ca}\left(\mathrm{NO}_{3}\right)_{2}$ & $16.5 \mathrm{a}$ & $25.7 \mathrm{a}$ & $24.1 \mathrm{a}$ & $25.3 \mathrm{~b}$ \\
\hline Ca thiosulfate & $12.7 \mathrm{~b}$ & $25.2 \mathrm{a}$ & $19.7 \mathrm{c}$ & $27.8 \mathrm{ab}$ \\
\hline $\mathrm{CaCl}_{2}$ & $14.2 \mathrm{~b}$ & $25.0 \mathrm{a}$ & $23.4 \mathrm{ab}$ & $30.0 \mathrm{a}$ \\
\hline $\mathrm{CaSO}_{4}$ & $14.2 \mathrm{~b}$ & $23.8 \mathrm{a}$ & $23.4 \mathrm{ab}$ & $28.5 \mathrm{ab}$ \\
\hline $1 / 2 \mathrm{KCl}$ & $14.1 \mathrm{~b}$ & $18.8 \mathrm{~b}$ & $23.7 \mathrm{a}$ & $21.3 \mathrm{c}$ \\
\hline \multicolumn{5}{|l|}{ Water treatment } \\
\hline $10 \mathrm{kPa}$ & $13.7 \mathrm{a}$ & $24.4 \mathrm{a}$ & $22.3 \mathrm{a}$ & $26.9 \mathrm{a}$ \\
\hline $25 \mathrm{kPa}$ & $14.5 \mathrm{a}$ & $23.3 \mathrm{a}$ & $22.5 \mathrm{a}$ & $26.6 \mathrm{a}$ \\
\hline
\end{tabular}

${ }^{2}$ Mean separation (in column) by Duncan's multiple range test.

Table 5. Main effects of nutritional treatment and water treatment on $2 \mathrm{~cm}$ fruit dry weight $\mathrm{Ca}$ and K concentrations sampled 57 dafter transplanting (DAT), Spring 2001 and 2002.

\begin{tabular}{|c|c|c|}
\hline & \multicolumn{2}{|c|}{ 2-cm Fruit concn $\left(\mathrm{g} \cdot \mathrm{kg}^{-1}\right)$} \\
\hline & \multicolumn{2}{|c|}{ Year } \\
\hline & 2001 & 2002 \\
\hline & $\mathrm{Ca}$ & $\mathrm{K}$ \\
\hline \multicolumn{3}{|c|}{ Nutritional treatment } \\
\hline No added $\mathrm{Ca}$ & $0.99{b c^{2}}^{2}$ & $36.0 \mathrm{a}^{\mathrm{z}}$ \\
\hline $\mathrm{Ca}\left(\mathrm{NO}_{3}\right)_{2}$ & $1.12 \mathrm{a}$ & $35.5 \mathrm{a}$ \\
\hline $\mathrm{Ca}$ thiosulfate & $0.83 \mathrm{~d}$ & $36.3 \mathrm{a}$ \\
\hline $\mathrm{CaCl}_{2}$ & $1.05 \mathrm{ab}$ & $36.9 \mathrm{a}$ \\
\hline $\mathrm{CaSO}_{4}$ & $0.90 \mathrm{~cd}$ & $35.9 \mathrm{a}$ \\
\hline $1 / 2 \mathrm{KCl}$ & $1.06 \mathrm{ab}$ & $31.6 \mathrm{~b}$ \\
\hline \multicolumn{3}{|l|}{ Fruit section } \\
\hline Stem end & $1.58 \mathrm{a}$ & $31.6 \mathrm{c}$ \\
\hline Middle & $0.74 \mathrm{~b}$ & $35.1 \mathrm{~b}$ \\
\hline Blossom end & $0.65 \mathrm{c}$ & $39.5 \mathrm{a}$ \\
\hline \multicolumn{3}{|l|}{ Water treatment } \\
\hline $10 \mathrm{kPa}$ & $1.08 \mathrm{a}$ & $35.4 \mathrm{a}$ \\
\hline $25 \mathrm{kPa}$ & $0.90 \mathrm{~b}$ & $35.3 \mathrm{a}$ \\
\hline
\end{tabular}

${ }^{\mathrm{z}}$ Mean separation (in column) by Duncan's multiple range test.

centrations of fruit decreased significantly from the stem-end section to the blossom-end section. The Ca concentrations of 2-cm fruit from plants irrigated at $10 \mathrm{kPa}$ were higher than from plants irrigated at $25 \mathrm{kPa}$. The $\mathrm{K}$ concentrations of 2- cm fruit sampled 57 DAT during 2001 from plants that received reduced $\mathrm{K}$ were lower than with other nutritional treatments. The $\mathrm{K}$ concentrations were unaffected by water treatment and increased significantly from the stem-end section to the blossomend section.

The $\mathrm{K}$ concentrations in 2001 and $\mathrm{Ca}$ concentrations in 2002 of 2-cm fruit sampled 57 DAT were affected by an interaction between nutritional treatment and water treatment (Table 6). During 2001 with irrigation at $10 \mathrm{kPa}$, the $\mathrm{K}$ concentrations of $2-\mathrm{cm}$ fruit from plants that received reduced $\mathrm{K}$ were lower than with other nutritional treatments. With irrigation at $25 \mathrm{kPa}$, the K concentrations of fruit with reduced $\mathrm{K}$ were lower than with $\mathrm{Ca}\left(\mathrm{NO}_{3}\right)_{2}, \mathrm{CaCl}_{2}$, and $\mathrm{CaSO}_{4}$. With both water treatments, the $\mathrm{K}$ concentrations increased significantly from the stem-end section to the blossom-end section. With irrigation at $10 \mathrm{kPa}$, the Ca concentrations of 2 -cm fruit from plants that received $\mathrm{CaCl}_{2}$ were higher than with $\mathrm{Ca}$ thiosulfate and $\mathrm{CaSO}_{4}$. With irrigation at 25 $\mathrm{kPa}$, the $\mathrm{Ca}$ concentrations of $2-\mathrm{cm}$ fruit from plants that received $\mathrm{Ca}\left(\mathrm{NO}_{3}\right)_{2}$ were higher than with no added $\mathrm{Ca}, \mathrm{Ca}$ thiosulfate, and $\mathrm{CaCl}_{2}$. During both years the $\mathrm{Ca}$ concentration was nearly 3 times higher in the stem-end than blossom-end and were almost 2 times higher in 2002 than 2001.

During 2001 the Ca concentrations of ripe fruit sampled 90DAT were affected by interactions between water treatment and nutritional treatment (Table 7). With irrigation at $10 \mathrm{kPa}$, the Ca concentrations of fruit from plants that received $\mathrm{Ca}\left(\mathrm{NO}_{3}\right)_{2}$ were higher than with other nutritional treatments. When irrigated at 25
$\mathrm{kPa}$, the $\mathrm{Ca}$ concentrations of ripe fruit from plants receiving any form of additional $\mathrm{Ca}$ were higher than with no added $\mathrm{Ca}$. Fruit $\mathrm{Ca}$ concentrations decreased 2-to 3 -fold from the stem-end section to the blossom-end section with both water treatments.

During 2002, the Ca concentrations of ripe fruit 90 DAT were not affected by nutritional treatment or water treatment (data not presented). The $\mathrm{Ca}$ concentrations were higher $\left(1.91 \mathrm{~g} \cdot \mathrm{kg}^{-1}\right)$ in the stem-end section of the fruit compared to the middle $\left(1.07 \mathrm{~g} \cdot \mathrm{kg}^{-1}\right)$ or blossom-end $\left(1.91 \mathrm{~g} \cdot \mathrm{kg}^{-1}\right)$ fruit sections, and were higher than ripe fruit in 2001 . The $\mathrm{K}$ concentrations of ripe fruit were higher during 2002 compared to 2001 (Table 8). The K concentrations were lower from plants that received reduced $\mathrm{K}$ than with other nutritional treatments. The K concentrations were unaffected by water treatment and, in contrast to Ca concentrations, increased for the stem-end section to the blossom-end section.

Plants that received $\mathrm{Ca}\left(\mathrm{NO}_{3}\right)_{2}$ had either the highest or were equivalent to the highest leaf, $2-\mathrm{cm}$ fruit, and ripe fruit $\mathrm{Ca}$ concentrations than with all other nutritional treatments during both seasons. These results suggest that reducing $\mathrm{NH}_{4}^{+}-\mathrm{N}$ by the supply of $\mathrm{N}$ as $\mathrm{NO}_{3}{ }^{-}$and adding supplemental $\mathrm{Ca}$ increases leaf and fruit $\mathrm{Ca}$ concentrations. Klougart (1980) found that the $\mathrm{NO}_{3}$ source of Ca was better than $\mathrm{Cl}$ or $\mathrm{SO}_{4}$ sources in nutrient solution for ensuring high concentrations of Ca uptake in tulips. Kleinhenz et al. (1999) showed that soluble Ca sources [e.g., $\mathrm{Ca}\left(\mathrm{NO}_{3}\right)_{2}$ ] increased $\mathrm{Ca}$ concentrations in nonperidermal potato tissue compared to $\mathrm{CaSO}_{4}$, suggesting it was due to the lower solubility of $\mathrm{CaSO}_{4}$. The Ca concentrations of leaves, 2-cm, and ripe fruit from plants that received reduced $\mathrm{K}$ sampled during the 2002 season were similar to the treatments that promoted the highest $\mathrm{Ca}$ concentrations. This suggests that reducing $\mathrm{K}$ inputs increases the uptake of $\mathrm{Ca}$.

The $\mathrm{Ca}$ concentrations of $2-\mathrm{cm}$ and ripe fruit stem-end sections were higher than the blossom-end sections during both seasons. The $\mathrm{Ca}$ concentrations of mid-fruit section were generally intermediate or statistically the same
Table 6. Interaction of nutritional treatment and water treatment on 2-cm fruit dry weight $\mathrm{Ca}$ and K concentrations sampled $57 \mathrm{~d}$ after transplanting (DAT), Spring 2001 and 2002.

\begin{tabular}{|c|c|c|c|c|}
\hline & \multicolumn{4}{|c|}{ 2-cm fruit concn $\left(\mathrm{g} \cdot \mathrm{kg}^{-1}\right)$} \\
\hline & \multicolumn{4}{|c|}{ Year } \\
\hline & \multicolumn{2}{|c|}{2001} & \multicolumn{2}{|c|}{2002} \\
\hline & \multicolumn{2}{|c|}{$\mathrm{K}$} & \multicolumn{2}{|c|}{$\mathrm{Ca}$} \\
\hline & \multicolumn{2}{|c|}{ Water treatment } & \multicolumn{2}{|c|}{ Water treatment } \\
\hline & $10 \mathrm{kPa}$ & $25 \mathrm{kPa}$ & $10 \mathrm{kPa}$ & $25 \mathrm{kPa}$ \\
\hline \multicolumn{5}{|c|}{ Nutritional treatment } \\
\hline No added $\mathrm{Ca}$ & $40.2 \mathrm{a}^{\mathrm{z}}$ & $38.1 \mathrm{ab}$ & $1.73 \mathrm{abc}^{2}$ & $1.43 \mathrm{bc}$ \\
\hline $\mathrm{Ca}\left(\mathrm{NO}_{3}\right)_{2}$ & $38.3 \mathrm{ab}$ & $39.3 \mathrm{a}$ & $1.80 \mathrm{ab}$ & $1.89 \mathrm{a}$ \\
\hline Ca thiosulfate & $38.2 \mathrm{ab}$ & $38.4 \mathrm{ab}$ & $1.55 \mathrm{bc}$ & $1.39 \mathrm{c}$ \\
\hline $\mathrm{CaCl}_{2}$ & $40.0 \mathrm{a}$ & $39.4 \mathrm{a}$ & $1.83 \mathrm{a}$ & $1.41 \mathrm{c}$ \\
\hline $\mathrm{CaSO}_{4}^{2}$ & $37.9 \mathrm{~b}$ & $39.5 \mathrm{a}$ & $1.52 \mathrm{c}$ & $1.71 \mathrm{ab}$ \\
\hline $1 / 2 \mathrm{KCl}^{4}$ & $33.0 \mathrm{c}$ & $36.8 \mathrm{~b}$ & $1.74 \mathrm{abc}$ & $1.69 \mathrm{ab}$ \\
\hline \multicolumn{5}{|l|}{ Fruit section } \\
\hline Stem end & $35.4 \mathrm{c}$ & $36.4 \mathrm{c}$ & $3.03 \mathrm{a}$ & $2.78 \mathrm{a}$ \\
\hline Middle & $37.6 \mathrm{~b}$ & $38.3 \mathrm{~b}$ & $1.08 \mathrm{~b}$ & $1.03 \mathrm{~b}$ \\
\hline Blossom end & $40.7 \mathrm{a}$ & $41.1 \mathrm{a}$ & $0.97 \mathrm{~b}$ & $0.95 \mathrm{~b}$ \\
\hline
\end{tabular}

${ }^{\mathrm{z}}$ Mean separation (in column) by Duncan's multiple range test.
Table 7. Interaction of nutritional treatment and water treatment on dry weight ripe fruit $\mathrm{Ca}$ concentrations divided into stem-end, middle, and blossom-end, sampled 90 daftertransplanting (DAT), Spring 2001.

\begin{tabular}{c}
\hline \multicolumn{2}{c}{ Ripe fruit Ca concn $\left(\mathrm{g} \cdot \mathrm{kg}^{-1}\right)$} \\
\cline { 2 - 2 }
\end{tabular}

Nutritional treatment

$\begin{array}{lll}\text { No added } \mathrm{Ca} & 1.18 \mathrm{~b}^{\mathrm{z}} \quad 0.84 \mathrm{c}\end{array}$

$\mathrm{Ca}\left(\mathrm{NO}_{3}\right)_{2} \quad 1.40 \mathrm{a} \quad 1.05 \mathrm{a}$

Ca thiosulfate $\quad 1.20 \mathrm{~b} \quad 1.08 \mathrm{a}$

$\begin{array}{lll}\mathrm{CaCl}_{2} & 1.16 \mathrm{~b} & 0.98 \mathrm{ab}\end{array}$

$\mathrm{CaSO}_{4} \quad 1.08 \mathrm{~b} \quad 1.10 \mathrm{a}$

$1 / 2 \mathrm{KCl} \quad 1.15 \mathrm{~b} \quad 0.86 \mathrm{bc}$

Fruit section

$\begin{array}{lll}\text { Stem end } & 1.74 \mathrm{a} & 1.52 \mathrm{a}\end{array}$

$\begin{array}{lll}\text { Middle } & 0.99 \mathrm{~b} & 0.77 \mathrm{~b}\end{array}$

Blossom end $\quad 0.86 \mathrm{c} \quad 0.67 \mathrm{c}$

${ }^{{ }^{2}}$ Mean separation (in column) by Duncan's multiple range test. 
Table 8. Main effects of year, nutritional treatment, irrigation treatment, and fruit section on dry weight ripe fruit $\mathrm{K}$ concentration sampled $90 \mathrm{~d}$ after transplanting (DAT), Spring 2001 and 2002.

\begin{tabular}{ll}
\hline & Ripe fruit $\mathrm{K} \mathrm{concn}\left(\mathrm{g} \cdot \mathrm{kg}^{-1}\right)$ \\
\hline Year & \\
2001 & $29.2 \mathrm{~b}^{\mathrm{z}}$ \\
2002 & $31.5 \mathrm{a}$ \\
Nutritional treatment & \\
$\mathrm{No}$ added Ca & $29.9 \mathrm{a}$ \\
$\mathrm{Ca}\left(\mathrm{NO}_{3}\right)_{2}$ & $31.0 \mathrm{a}$ \\
$\mathrm{Ca}$ thiosulfate & $30.8 \mathrm{a}$ \\
$\mathrm{CaCl}$ & $32.1 \mathrm{a}$ \\
$\mathrm{CaSO}$ & $30.8 \mathrm{a}$ \\
$1 / 2 \mathrm{KCl}_{4}$ & $27.6 \mathrm{~b}$ \\
Water treatment & \\
$10 \mathrm{kPa}$ & $29.9 \mathrm{a}$ \\
$25 \mathrm{kPa}$ & $30.8 \mathrm{a}$ \\
Fruit section & \\
Stem end & $28.1 \mathrm{c}$ \\
Middle & $30.2 \mathrm{~b}$ \\
Blossom end & $32.7 \mathrm{a}$ \\
\hline
\end{tabular}

${ }^{\text {z} M e a n ~ s e p a r a t i o n ~(i n ~ c o l u m n) ~ b y ~ D u n c a n ' s ~ m u l t i p l e ~}$ range test.

as the blossom-end section of the fruit. Frost and Kretchman (1989) divided cucumbers into four equal transverse sections and found a $\mathrm{Ca}$ gradient existed within the fruit. The proximal peduncle portion contained the highest concentration of $\mathrm{Ca}$, while the distal section contained the lowest. In a study by Tadesse et al. (2001), sweet pepper fruit blossom-end sections had lower Ca concentrations than the stem-end sections of the fruit.

Temperature, daily ET, and fruit Ca concentrations were higher and rainfall was lower in 2002 compared to 2001. Both high temperature and low rainfall causes lower humidity. In a study by Tadesse et al. (2001), lower relative humidity promoted the uptake and accumulation of $\mathrm{Ca}$ into the blossom-end portion of sweet pepper compared to uptake with a higher relative humidity. With higher ET, more water moves through the plant and since $\mathrm{Ca}$ moves with the transpiration stream, more Ca moves into the plant and fruit. Quintana et al. (1999) suggested differences in bean Ca concentration from year to year were due to variations in rainfall, temperature, and other environmental factors. In the study, beans that had higher $\mathrm{Ca}$ concentrations were grown during the season that was higher in temperature.

Ripe fruit K concentrations were higher during 2002 than in 2001 (Table 8). Leaf, ripe fruit, and $2-\mathrm{cm}$ fruit $\mathrm{K}$ concentrations from plants that received reduced $\mathrm{K}$ had the lowest fruit $\mathrm{K}$ concentrations compared to fruit with other nutritional treatments, except 2-cm fruit during 2001 with irrigation at $25 \mathrm{kPa}$, where they were similar. Locascio et al. (1997) also found linear increases in $\mathrm{K}$ fertilization generally led to linear increases in tomato leaf $\mathrm{K}$ concentration.

Nutrient concentrations of soils samples, taken 51 DAT during 2001 and 2002, are presented in Table 9. Soil K concentrations were lower from plots that received reduced K compared with other nutritional treatments. Soil Ca concentrations were higher from plots that received $\mathrm{CaSO}_{4}$ compared with other nutri-
Table 9. Main effects of nutritional treatment and water treatment on soil $\mathrm{K}$ and $\mathrm{Ca}$ concentrations sampled $51 \mathrm{~d}$ after transplanting (DAT), spring 2001 and 2002.

\begin{tabular}{lrc}
\hline & \multicolumn{2}{c}{ Soil $\left(\mathrm{mg} \cdot \mathrm{kg}^{-1}\right)$} \\
\cline { 2 - 3 } & $\mathrm{K}$ & $\mathrm{Ca}$ \\
\hline Year & & \\
2001 & $103.5 \mathrm{a}$ & $357.1 \mathrm{~b}$ \\
2002 & $89.2 \mathrm{~b}$ & $393.2 \mathrm{a}$ \\
Nutritional treatment & \\
No added Ca & $109.5 \mathrm{a}$ & $332.6 \mathrm{~cd}$ \\
$\mathrm{Ca}\left(\mathrm{NO}_{3}\right)_{2}$ & $100.5 \mathrm{a}$ & $412.2 \mathrm{~b}$ \\
$\mathrm{Ca}$ thiosulfate & $114.1 \mathrm{a}$ & $296.2 \mathrm{~d}$ \\
$\mathrm{CaCl}$ & $99.3 \mathrm{a}$ & $362.3 \mathrm{bc}$ \\
$\mathrm{CaSO}$ & & $503.7 \mathrm{a}$ \\
$1 / 2 \mathrm{KCl}$ & $99.6 \mathrm{a}$ & $343.8 \mathrm{~cd}$ \\
Water treatment & $55.1 \mathrm{~b}$ & \\
$10 \mathrm{kPa}$ & & $370.9 \mathrm{a}$ \\
$25 \mathrm{kPa}$ & $107.8 \mathrm{a}$ & $379.4 \mathrm{a}$ \\
\hline${ }^{\mathrm{z}} \mathrm{Mean}$ separation (in column) by Duncan's multiple \\
range test.
\end{tabular}

tional treatments, and $\mathrm{Ca}$ concentrations with $\mathrm{Ca}$ thiosulfate were lower than with $\mathrm{Ca}\left(\mathrm{NO}_{3}\right)_{2}$ or $\mathrm{CaCl}_{2}$. Water treatment had no effect on soil Ca concentrations. Plots irrigated at $10 \mathrm{kPa}$ had a lower $\mathrm{K}$ concentration than with irrigation at $25 \mathrm{kPa}$. Soil Ca concentrations were higher and the $\mathrm{K}$ concentrations were lower in 2002 compared to 2001. These differences most likely increased $\mathrm{Ca}$ uptake by the plant.

The incidence of BER was not completely alleviated by treatments used in this study; these effects may be due to the limited capacity of the plant to regulate the internal distribution of $\mathrm{Ca}$, in particular the continued flow towards organs with low ET and rapid growth such as fruit (Franco et al., 1994). In this study leaf and fruit $\mathrm{Ca}$ concentrations were generally higher in the 2002 season compared to the 2001 season, due to application of more Ca containing irrigation water, higher daily ET, and lower soil K concentrations. Paiva et al. (1998b) in a greenhouse study showed an increase in fruit transpiration was more effective in increasing fruit $\mathrm{Ca}$ concentrations than increasing $\mathrm{Ca}$ concentration in the substrate.

The lowest $\mathrm{Ca}$ concentration was observed at the blossom-end of fruit from plants irrigated at $25 \mathrm{kPa}$ during the 2001 season, which had over 5 times the amount of BER compared to the 2002 season. These data indicate that BER was a symptom of $\mathrm{Ca}$ deficiency and this deficiency was aggravated by low ET and the low amount of irrigation water supplied in 2001. During 2002, incidence of BER was unaffected by nutritional treatment. Plants irrigated at $10 \mathrm{kPa}$ had less incidence of BER compared to plants irrigated at $25 \mathrm{kPa}$. The 2002 season had higher temperatures, higher ET, much less rainfall, and hence, higher $\mathrm{Ca}$ uptake by the plants, compared to 2001. Due to the reduced rainfall in 2002, much more $\mathrm{Ca}$ containing irrigation water was applied during the 2002 season. This suggests that when irrigation water is high in $\mathrm{Ca}$ and there is minimal rainfall and high ET, additional $\mathrm{Ca}$ fertilization may not be necessary to reduce the incidence of BER.

With increasing restrictions on water and fertilizer use, prevention of BER may become even more difficult. Interactions of mineral elements in the soil and in the plant together with synergistic and antagonistic effects are constantly new problems that call for the researcher's attention(Gunes etal., 1998). Most research on relationships between water and nutrients on tomato BER has been conducted in greenhouses. Field research has been limited. With tomato production in a sandy soil, it was essential to maintain soil matric potential at $10 \mathrm{kPa}$ compared with $25 \mathrm{kPa}$ to decrease incidence of BER, particularly in seasons with high rainfall and low ET.

\section{Literature Cited}

DeKock, P., A. Hall, R. Boggie, and R. Inkson. 1982. The effect of water stress and form of nitrogen on the incidence of blossom-end rot in tomatoes. J. Sci. Food Agr. 33:509-515.

English, J.E. and A.V. Barker. 1983. Calcium efficiency among tomato strains depends on nitrogen regimes. J. Plant Nutr. 6:725-734.

Franco, J.A., S. Banon, and R. Madrid. 1994. Effects of a protein hydrolysate applied by fertigation on the effectiveness of calcium as a corrector of blossom-end rot in tomato cultivated under saline conditions. Sci. Hort. 57:283-292.

Franco, J.A., P.J. Perez-Saura, J.A. Fernandez, M. Parra, and A.L. Garcia. 1999. Effect of two irrigation rates on yield, incidence of blossomend rot, mineral content, and free amino acid levels in tomato cultivated under drip irrigation using saline water. J. Hort. Sci. Biotechnol. 74:430-435

Frost, D.J. and D.W. Kretchman. 1989. Calcium deficiency reduces cucumber fruit and seed quality. J. Amer. Soc. Hort. Sci. 114:552-556.

Galloway, B.T. 1888. Notes on the black-rot of tomatoes. USDA Rpt. Commissioner Agr. 339-345.

Geraldson, C.M. 1955. The use of calcium for control of blossom-end rot of tomatoes. Proc. Fla. State Hort. Soc. 68:197-202.

Geraldson, C.M. 1956. Evaluation of control methods for blackheart of celery and blossomend rot of tomatoes. Proc. Fla. State Hort. Soc. 69:236-241.

Gunes, A., M. Alpaslan, and A. Inal. 1998. Critical nutrient concentrations and antagonistic and synergistic relationships among the nutrients of NFT-grown young tomato plants. J. Plant Nutr. 21:2035-2047.

Hanger, B.C. 1979. The movement of calcium in plants. Comm. Soil Sci. Plant Anal. 10:171193.

Ho, L.C., P. Adams, X.Z. Li, H. Shen, J. Andrews, and Z.H. Xu. 1995. Response of calcium-inefficient tomato cultivars to salinity in plant growth, calcium accumulation and blossom-end rot. J. Hort. Sci. 70:909-918.

Kalra, Y.P. 1998. Handbook of reference methods for plant analysis. CRC Press, Boca Raton, Fla.

Keiser, J.R. and R.E. Mullen. 1993. Calcium and relative humidity effects on soybean seed nutrition and seed quality. Crop Sci. 33:1345-1349.

Kirby, E.A. and D.J. Pilbeam. 1984. Calcium as a plant nutrient. Plant Cell Environ. 7:397-405.

Kitano, M., T. Araki, S. Yoshida, and T. Eguchi. 1999. Dependence of calcium uptake on water absorption and respiration in roots of tomato plants (Lycopersicon esculentum Mill.). Biotronics 28:121-130.

Kleinhenz, M.D., J.P. Palta, and C.C. Gunter. 1999. Impact of source and timing of calcium and nitrogen applications on 'Atlantic' potato tuber 
calcium concentrations and internal quality. J. Amer. Soc. Hort. Sci. 124:498-506.

Klougart, A. 1980. Calcium uptake of tulips during forcing. Acta Hort. 109:89-95.

Kreij, C. 1996. Interactive effect of air humidity, calcium, and phosphate on blossom end rot, leaf deformation, production, and nutrient contents of tomato. J. Plant Nutr. 19:361-377.

Locascio, S.J., J.A. Bartz, and D.P. Weingartner 1991. Potato yield and soft-rot potential as influenced by calcium and potassium fertilization. Proc. Fla. State Hort. Soc. 104: 248-253.

Locascio, S.J., G.J. Hochmuth, S.M. Olson, R.C. Hochmuth, A.A. Csizinszky, and K.D. Shuler. 1997. Potassium source and rate for polyethylene-mulched tomatoes. HortScience 32:1204-1207.

Locascio, S.J. and A.G. Smajstrla. 1996. Water application scheduling by pan evaporation for drip-irrigated tomato. J. Amer. Soc. Hort. Sci. 121:63-68.

Marcelis, L.F.M. and L.C. Ho. 1999. Blossom-end rot in relation to growth rate and calcium contents in fruits of sweet pepper (Capsicum anпиит L.). J. Expt. Bot. 50:357-363.

Marschner, H. 1997. Mineral nutrition of higher plants. 2nd ed. Academic, San Diego, Calif.
McLaughlin, S.B. and R. Wimmer. 1999. Tansley review No. 104 calcium physiology and terrestrial ecosystem processes. New. Phytol. 142:373-417.

Page, A.L., R.H. Miller, and D.R. Keeney. 1982 Methods of soil analysis, part 2. Chemical and microbiological properties. 2nd ed. Soil Sci. Soc. Amer. Madison, Wis.

Paiva, E.A.S., H.E.P. Martinez, V.W.D. Casali, and L. Padilha. 1998a. Occurrence of blossom-end rot in tomato as a function of calcium dose in the nutrient solution and air relative humidity. J. Plant Nutr. 21:2663-2670.

Paiva, E.A.S., R.A. Sampaio, and H.E.P. Martinez. 1998b. Composition and quality of tomato fruit cultivated in nutrient solutions containing different calcium concentrations. J. Plant Nutr. 21:2653-2661.

Quintana, J.M., H.C. Harrison, J. Nienhuis, J.P. Palta, and K. Kmiecik. 1999. Comparison of pod calcium concentration between two snap bean populations. J. Amer. Soc. Hort. Sci 124:273-276

Raleigh, S.M. and J.A. Chucka. 1944. Effect of nutrient ratio and concentration on growth and composition of tomato plants and on the oc- currence of blossom-end rot of the fruit. Plant Physiol. 19:671-678.

Reid, J.B., D. Winfield, I. Sorensen, and A.J. Kale. 1996. Water deficit, root demography, and the cause of internal blackening in field-grown tomatoes (Lycopersicon esculentum Mill.). Ann. Appl. Biol. 129:1370-149.

Saure, M.C. 2001. Review: Blossom-end rot of tomato (Lycopersicon esculentum Mill.)-A calcium- or a stress-related disorder? Sci. Hort. 90:193-208.

Smajstrla, A.G. and S.J. Locascio. 1996. Tensiometer-controlled, drip-irrigation scheduling of tomato. Appl. Eng. Agr. 12:315-319.

Tadesse, T., M.A. Nichols, E.W. Hewett, and K.J. Fisher. 2001. Relative humidity around the fruit influence the mineral composition and incidence of blossom-end rot in sweet pepper. J. Hort. Sci. Biotechnol. 76:9-16.

U.S. Dept. of Agriculture. 1976. United States standards for grades of fresh tomatoes. USDA, Agr. Mktg. Serv., Washington, D.C.

Willumsen, J., K.K. Petersen, and K. Kaack. 1996. Yield and blossom-end rot of tomato as affected by salinity and cation activity ratios in the root zone. J. Hort. Sci. 71:81-98. 